\title{
Isolation of new fuzanins, carbamate-containing natural products, from Kitasatospora sp. IFM10917
}

\author{
Kazuya Maekawa, Kazufumi Toume and Masami Ishibashi
}

The Journal of Antibiotics (2010) 63, 385-388; doi:10.1038/ja.2010.54; published online 9 June 2010

Keywords: carbamate; fuzanin; Kitasatospora sp.

During our studies on the search for bioactive natural products from various sources, ${ }^{1}$ we have investigated bioactive metabolites of actinomycete strains and isolated a new tyramine derivative ${ }^{2}$ or teleocidin derivative $^{3}$ in our screening studies targeting tumor necrosis-factorrelated apoptosis-inducing ligand signaling. ${ }^{4}$ Conversely, we recently investigated the chemical constituents of Kitasatospora sp. IFM10917, based on TLC examination using anisaldehyde as a spray reagent, and isolated new carbamate- and pyridine-containing compounds, named fuzanins A-D. ${ }^{5}$ We further investigated the culture of Kitasatospora sp. IFM10917 and performed chemical studies on its extract, resulting in the isolation of further carbamate-containing metabolites, named fuzanins E-I (1-5) (Figure 1). Herein we describe the isolation and structural elucidation of these new compounds.

The cultured supernatant of Kitasatospora sp. IFM10917 was partitioned between ethyl acetate (EtOAc) and water. The EtOAc-soluble fraction was subjected to silica gel column chromatography, followed by purification with Sephadex LH-20 column (GE Healthcare BioSciences, Uppsala, Sweden) and reversed-phase HPLC on ODS to give five new compounds, fuzanins E-I (1-5).

Fuzanin E (1) was revealed to have the molecular formula of $\mathrm{C}_{14} \mathrm{H}_{21} \mathrm{NO}_{4}$ on the basis of high-resolution fast atom bombardment mass spectroscopy (HRFABMS) at $\mathrm{m} / z 268.1560\left((\mathrm{M}+\mathrm{H})^{+}\right.$, $\Delta+1.1 \mathrm{mmu})$. Absorption at 3360 and $1740 \mathrm{~cm}^{-1}$ in the IR spectrum suggested the presence of hydroxyl and carbonyl groups, respectively. The ${ }^{13} \mathrm{C}$ NMR spectrum (Table 1) showed 14 signals, which were assigned to two methyls $\left(\delta_{\mathrm{C}} 23.7\right.$ and 18.0), three aliphatic methylenes $\left(\delta_{\mathrm{C}} 28.2,37.9\right.$ and 44.6$)$, four heteroatom-bearing methines $\left(\delta_{\mathrm{C}} 60.5\right.$, 62.9, 67.4 and 80.6), three $\mathrm{sp}^{2}$ methines $\left(\delta_{\mathrm{C}} 127.7,126.8\right.$ and 137.8), one $\mathrm{sp}^{2}$ quaternary carbon $\left(\delta_{\mathrm{C}} 133.2\right)$ and one carbonyl carbon $\left(\delta_{\mathrm{C}}\right.$ 156.4); the ${ }^{13} \mathrm{C}$ chemical shift of this carbonyl group indicated that it was located between oxygen and nitrogen atoms, suggesting that $\mathbf{1}$ had a carbamate moiety. The ${ }^{1} \mathrm{H}$ NMR spectrum of 1 (Table 1 ) revealed signals due to two methyls $\left(\delta_{\mathrm{H}} 1.21(3 \mathrm{H}, \mathrm{d}, J=6.4 \mathrm{~Hz})\right.$ and 1.69 $(3 \mathrm{H}, \mathrm{s}))$, one heteroatom-bearing methylene $\left(\delta_{\mathrm{H}} 2.69\right.$ and 4.20$)$, four heteroatom-bearing methines $\left(\delta_{\mathrm{H}} 3.82,3.88,4.35\right.$ and 4.48) and three olefinic protons $\left(\delta_{\mathrm{H}} 5.58,5.64\right.$ and 5.94$)$. These ${ }^{1} \mathrm{H}$ and ${ }^{13} \mathrm{C} \mathrm{NMR}$ spectral data were similar to those of fuzanin B (6) (Figure 1), except for the number of double bonds. Fuzanin B (6) possessed a two disubstituted diene, whereas fuzanin $\mathrm{E}$ (1) had one disubstituted olefin and two more $\mathrm{sp}^{3}$ methylene groups. The ${ }^{1} \mathrm{H}-{ }^{1} \mathrm{H}$ COSY spectrum of 1 revealed ${ }^{1} \mathrm{H}$-connectivities from $\mathrm{H}_{2}-2$ to $\mathrm{H}-3$ and from $\mathrm{H}-6$ to $\mathrm{H}-13$, and the disubstituted olefin was shown to be at C-8 and C-9 and a secondary hydroxyl group at C-12 position from the COSY correlation data. The large coupling constants $\left(J_{8,9}=14.9 \mathrm{~Hz}\right)$ suggested the E-configurations of $\Delta^{8,9}$-double bonds. The HMBC spectrum of $\mathbf{1}$ also suggested that fuzanin E (1) had the same bicyclic ring system as fuzanin $\mathrm{B}(\mathbf{6})$ containing a carbamate group $\left(\mathrm{H}_{2}-2 / \mathrm{C}-3, \mathrm{H}_{2}-2 / \mathrm{C}-4, \mathrm{H}_{2}-2 / \mathrm{C}-6, \mathrm{H}_{2}-2 / \mathrm{C}-15, \mathrm{H}-4 / \mathrm{C}-6, \mathrm{H}-7 / \mathrm{C}-5\right.$, $\mathrm{H}-7 / \mathrm{C}-8, \mathrm{H}_{2}-10 / \mathrm{C}-8, \mathrm{H}_{2}-10 / \mathrm{C}-9, \mathrm{H}_{2}-10 / \mathrm{C}-11, \mathrm{H}_{2}-10 / \mathrm{C}-12, \mathrm{H}_{3}-13 /$ $\mathrm{C}-11, \mathrm{H}_{3}-13 / \mathrm{C}-12, \mathrm{H}_{3}-14 / \mathrm{C}-4, \mathrm{H}_{3}-14 / \mathrm{C}-5$ and $\left.\mathrm{H}_{3}-14 / \mathrm{C}-6\right)$. The relative configuration of 1 was suggested by ${ }^{1} \mathrm{H}_{-}{ }^{1} \mathrm{H}$ coupling constants and NOE experiments. A large vicinal coupling constant $(J=9.4 \mathrm{~Hz})$ was observed between $\mathrm{H}-2 \beta$ and $\mathrm{H}-3$, indicating that $\mathrm{H}-2 \beta$ and $\mathrm{H}-3$ were trans-diaxial. NOE correlations were observed for $\mathrm{H}-2 \alpha / \mathrm{H}-3, \mathrm{H}-2 \beta / \mathrm{H}-$ 6 and $H-6 / H-8$ revealed that $H-2 \beta, H-6$ and $H-8$ were on the same side of the plane, whereas $\mathrm{H}-2 \alpha$ and $\mathrm{H}-3$ were on the other side. The absolute configurations at C-3 and C-12 of 1 were elucidated by applying the modified Mosher's method. ${ }^{6}$ Differences in the chemical shifts $\left(\Delta \delta\right.$ values: $\left.\delta_{S}-\delta_{R}\right)$ of the ${ }^{1} \mathrm{H}$ NMR spectra of $(S)$ - and $(R)$ MTPA ( $\alpha$-methoxy- $\alpha$-(trifluoromethyl)phenylacetic acid) diesters are shown in Table 2. Diagnostic positive $\Delta \delta$ values were observed for $\mathrm{H}-4, \mathrm{H}_{3}-13$ and $\mathrm{H}_{3}-14$, and negative $\Delta \delta$ values for $\mathrm{H}-2 \alpha, \mathrm{H}-2 \beta$ and $\mathrm{H}_{2}-11$. These findings led to assignment of the $3 R, 12 R$-configuration. On the basis of these results, the structure of fuzanin $E$ was concluded as 1, including the absolute configurations assigned as $3 R, 6 S, 7 S, 12 R$.

The high-resolution electron spray ionization mass spectra (HRESIMS) of fuzanin F (2) exhibited a quasi-molecular ion peak at $\mathrm{m} / \mathrm{z} 290.1358\left((\mathrm{M}+\mathrm{Na})^{+}, \Delta-0.5 \mathrm{mmu}\right)$, indicating the molecular formula $\mathrm{C}_{14} \mathrm{H}_{21} \mathrm{NO}_{4}$. The ${ }^{1} \mathrm{H}$ and ${ }^{13} \mathrm{C}$ NMR spectra of 2 (Table 1) 
were almost identical to those of $\mathbf{1}$, except for the signals of positions C-6, C-7 and C-8. The ${ }^{1} \mathrm{H}$ NMR chemical shifts due to $\mathrm{H}-6\left(\delta_{\mathrm{H}} 4.31\right)$, $\mathrm{H}-7\left(\delta_{\mathrm{H}} 4.98\right)$ and $\mathrm{H}-8\left(\delta_{\mathrm{H}} 5.33\right)$ for 2 were significantly different from those for $1\left(\delta_{\mathrm{H}} 3.88(\mathrm{H}-6), \delta_{\mathrm{H}} 4.48(\mathrm{H}-7)\right.$ and $\left.\delta_{\mathrm{H}} 5.64(\mathrm{H}-8)\right)$ (Table 2), whereas the three carbon signals at $\delta_{\mathrm{C}} 58.0(\mathrm{C}-6), \delta_{\mathrm{C}} 78.6$ $(\mathrm{C}-7)$ and $\delta_{\mathrm{C}} 122.9(\mathrm{C}-8)$ in 2 resonated in higher fields than those of $1\left(\delta_{\mathrm{C}} 60.5(\mathrm{C}-6), \delta_{\mathrm{C}} 80.6(\mathrm{C}-7)\right.$ and $\left.\delta_{\mathrm{C}} 126.8(\mathrm{C}-8)\right)$. From these findings, $\mathbf{2}$ was suggested as a stereoisomer of $\mathbf{1}$ at position $\mathrm{C}-7$, which was also supported by the significant NOE correlations between H-6 and $\mathrm{H}-7$ for 2, instead of the correlation between $\mathrm{H}-6$ and $\mathrm{H}-8$ observed for $\mathbf{1}$. The absolute configuration of 2 was determined as $3 R, 12 R$ configurations using the modified Mosher's method (Table 3).<smiles>CC1=C[C@@H](O)CN2C(=O)O[C@H](/C=C/C=C/[C@H](C)O)[C@@H]12</smiles>

1<smiles>CC(=O)CC/C=C/[C@H]1OC(=O)N2C[C@H](O)C=C(C)[C@H]12</smiles>

3<smiles>CC(O)CC/C=C/[C@H]1OC(=O)N2CC[C@@H](O)[C@H](C)[C@H]12</smiles>

5<smiles>CC1=C[C@H](O)CN2C(=O)O[C@H](/C=C/CC[C@H](C)O)C[C@H]12</smiles>

2<smiles>CC(=O)CC/C=C/[C@H]1OC(=O)N2C[C@H](O)C=C(C)[C@H]12</smiles>

4

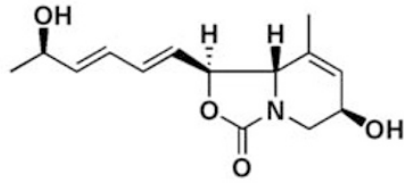

6
From these results, the structure of fuzanin $\mathrm{F}$ was revealed as $\mathbf{2}$ with $3 R, 6 S, 7 S, 12 R$ configurations.

Fuzanin G (3) was shown to have a molecular formula of $\mathrm{C}_{14} \mathrm{H}_{19} \mathrm{NO}_{4}$ from HRFABMS data at $\mathrm{m} / z 288.1199\left((\mathrm{M}+\mathrm{Na})^{+}\right.$, $\Delta-2.2 \mathrm{mmu}$ ). The ${ }^{1} \mathrm{H}$ and ${ }^{13} \mathrm{C}$ NMR spectra of 3 (Table 1 ) were similar to those of 1 except for the presence of a ketone $\left(\delta_{C} 207.3\right)$ for 3 in place of an oxymethine at C-12 for $\mathbf{1}$. The C-13 methyl signal of 3 was observed as a singlet $\left(\delta_{\mathrm{H}} 2.15,(3 \mathrm{H}, \mathrm{s})\right)$. Thus, the structure of fuzanin $\mathrm{G}(\mathbf{3})$ was inferred as a 12-dehydro derivative of fuzanin $\mathrm{E}(\mathbf{1})$, which was further supported by the ${ }^{1} \mathrm{H}-{ }^{1} \mathrm{H}$ COSY and $\mathrm{HMBC}$ spectra (data not shown). The relative configuration between H-6 and H-7 of 3 was deduced as anti from the comparison of the ${ }^{1} \mathrm{H}$ chemical shifts of H-6 $\left(\delta_{\mathrm{H}} 3.87\right), \mathrm{H}-7\left(\delta_{\mathrm{H}} 4.46\right)$ and $\mathrm{H}-8\left(\delta_{\mathrm{H}} 5.63\right)$ as discussed above in the case of fuzanin E (1) and F (2), as shown in Table 2. This configuration was also consistent with the observation of significant NOE from $\mathrm{H}-6$ to $\mathrm{H}-8$ for 3 . The absolute configuration was determined as $3 R$ based on the modified Mosher's method (Table 3). Thus, the structure 3 was assigned to fuzanin G.

The molecular formula of fuzanin $\mathrm{H}(4), \mathrm{C}_{14} \mathrm{H}_{19} \mathrm{NO}_{4}$, determined by the HRESIMS data at $m / z 288.1201\left((\mathrm{M}+\mathrm{Na})^{+}, \Delta-0.5 \mathrm{mmu}\right)$ was the same as that of fuzanin $\mathrm{G}(3)$. The ${ }^{1} \mathrm{H}$ and ${ }^{13} \mathrm{C}$ NMR spectral data of 4 (Table 1) were almost identical to those of 3 , except for the chemical shifts of $\mathrm{H}-6, \mathrm{H}-7$ and $\mathrm{H}-8$ positions, which were diagnostic for the configuration for $\mathrm{H}-6 / \mathrm{H}-7$ (vide supra). On the basis of the comparison data in Table 2, the relative configuration of $\mathrm{H}-6 / \mathrm{H}-7$ was suggested as syn. Thus, fuzanin $\mathrm{H}$ (4) was deduced as a C-7 epimer of

Table 2 Comparison of the ${ }^{1} \mathrm{H}$ NMR chemical shifts of $\mathrm{H}-6, \mathrm{H}-7$ and $\mathrm{H}-8$, and assignment of relative configurations between $\mathrm{H}-6$ and $\mathrm{H}-7$

\begin{tabular}{lccccc}
\hline Positions & $\mathbf{1}$ & $\mathbf{2}$ & $\mathbf{3}$ & $\mathbf{4}$ & $\mathbf{5}$ \\
\hline $\mathrm{H}-6$ & 3.88 & 4.31 & 3.87 & 4.30 & 3.39 \\
$\mathrm{H}-7$ & 4.48 & 4.98 & 4.46 & 4.96 & 4.49 \\
$\mathrm{H}-8$ & 5.64 & 5.33 & 5.63 & 5.32 & 5.57 \\
Configuration of H-6/H-7 & Anti & Syn & Anti & Syn & Anti \\
\hline
\end{tabular}

Figure 1 Structures of $1-6$.

Table $1{ }^{1} \mathrm{H}$ and ${ }^{13} \mathrm{C}$ NMR spectral data for fuzanins $\mathrm{E}(1), \mathrm{F}(2), \mathrm{G}(3), \mathrm{H}(4)$ and I (5) in $\mathrm{CDCl}_{3}$

\begin{tabular}{|c|c|c|c|c|c|c|c|c|c|c|}
\hline \multirow[b]{2}{*}{ Position } & \multicolumn{2}{|l|}{1} & \multicolumn{2}{|l|}{2} & \multicolumn{2}{|l|}{3} & \multicolumn{2}{|l|}{4} & \multicolumn{2}{|l|}{5} \\
\hline & $\delta_{H}$ & $\delta_{C}$ & $\delta_{H}$ & $\delta_{C}$ & $\delta_{H}$ & $\delta_{C}$ & $\delta_{H}$ & $\delta_{C}$ & $\delta_{H}$ & $\delta_{C}$ \\
\hline$(\alpha)$ & $4.20 \mathrm{dd}(12.8,6.7)$ & 44.6 & $4.19 \mathrm{dd}(12.3,6.3)$ & 44.5 & $4.19 \mathrm{dd}(12.8,6.8)$ & 44.6 & 4.19 dd $(12.4,6.3)$ & 44.5 & 3.71 ddd $(12.9,5.6,1.7)$ & 36.5 \\
\hline$(\beta)$ & $2.69 \mathrm{dd}(12.8,9.4)$ & & $2.64 \mathrm{dd}(12.3,9.3)$ & & $2.69 \mathrm{dd}(12.8,9.6)$ & & $2.64 \mathrm{dd}(12.4,9.2)$ & & $3.22 \mathrm{td}(12.9,3.9)$ & \\
\hline 3 & $4.35 \mathrm{~m}$ & 62.9 & $4.27 \mathrm{~m}$ & 63.5 & $4.35 \mathrm{~m}$ & 62.8 & $4.27 \mathrm{~m}$ & 63.5 & $1.72-1.81 \mathrm{~m} \mathrm{(2H)}$ & 33.6 \\
\hline 6 & $3.88 \mathrm{~d}(8.0)$ & 60.5 & $4.31 \mathrm{~d}(8.0)$ & 58.0 & $3.87 \mathrm{~d}(7.8)$ & 60.5 & $4.30 \mathrm{~d}(8.0)$ & 58.0 & $3.39 \mathrm{dd}(10.5,7.1)$ & 60.4 \\
\hline 7 & $4.48 \mathrm{t}(8.0)$ & 80.6 & $4.98 \mathrm{t}(8.0)$ & 78.6 & $4.46 \mathrm{t}(7.8)$ & 80.3 & $4.96 \mathrm{t}(8.0)$ & 78.3 & $4.49 \mathrm{t}(7.1)$ & 80.0 \\
\hline 8 & $5.64 \mathrm{dd}(14.9,8.0)$ & 126.8 & $5.33 \mathrm{dd}(15.4,8.0)$ & 122.9 & $5.63 \mathrm{dd}(15.5,7.8)$ & 127.4 & $5.32 \mathrm{dd}(15.4,8.0)$ & 123.5 & $5.57 \mathrm{dd}(14.2,7.1)$ & 124.2 \\
\hline 9 & $5.94 \mathrm{dt}(14.9,7.3)$ & 137.8 & $5.89 \mathrm{dt}(15.4,7.1)$ & 137.9 & $5.92 \mathrm{dt}(15.5,6.8)$ & 136.2 & $5.86 \mathrm{dt}(15.4,8.0)$ & 136.5 & $5.94 \mathrm{dt}(14.2,6.9)$ & 133.3 \\
\hline 10 & $2.22 \mathrm{~m} \mathrm{(2H)}$ & 28.2 & $2.15 \mathrm{~m}(2 \mathrm{H})$ & 28.5 & $2.38 \mathrm{~m}(2 \mathrm{H})$ & 26.1 & $2.32 \mathrm{~m}(2 \mathrm{H})$ & 26.0 & $2.19 \mathrm{~m} \mathrm{(2H)}$ & 30.6 \\
\hline 11 & $1.54 \mathrm{~m}(2 \mathrm{H})$ & 37.9 & $1.52 \mathrm{~m} \mathrm{(2H)}$ & 37.9 & $2.56 \mathrm{t}(6.5)(2 \mathrm{H})$ & 42.0 & $2.51 \mathrm{t}(7.0)(2 \mathrm{H})$ & 42.3 & $1.60 \mathrm{~m}(2 \mathrm{H})$ & 39.4 \\
\hline
\end{tabular}

aNot observed. 
Table $3 \Delta \delta$ values $\left(\delta_{S}-\delta_{R}\right)$ of (S)- and (R)-MTPA esters of 1-4

\begin{tabular}{lcccc}
\hline Positions & $\mathbf{1}$ & $\mathbf{2}$ & $\mathbf{3}$ & $\mathbf{4}$ \\
\hline $2 \alpha$ & -0.037 & -0.011 & -0.036 & -0.018 \\
$2 \beta$ & -0.167 & -0.124 & -0.119 & -0.120 \\
$3 \delta$ & - & - & - & - \\
$3 \beta$ & - & - & - & - \\
4 & +0.094 & +0.004 & +0.036 & +0.111 \\
5 & - & - & - & - \\
$11(2 \mathrm{H})$ & -0.043 & -0.105 & - & - \\
$13(3 \mathrm{H})$ & +0.005 & +0.001 & - & - \\
$14(3 \mathrm{H})$ & +0.023 & +0.024 & +0.028 & - \\
\hline
\end{tabular}

aNot assigned due to overlapping.

fuzanin G (3), and the absolute configuration was determined as $3 R$ from the modified Mosher's method (Table 3).

Fuzanin I (5) had a molecular formula of $\mathrm{C}_{14} \mathrm{H}_{23} \mathrm{NO}_{4}$, revealed from the HRESIMS data at $\mathrm{m} / z 292.1513\left((\mathrm{M}+\mathrm{Na})^{+}, \Delta-1.2 \mathrm{mmu}\right)$, having two more hydrogen atoms than fuzanin $\mathrm{E}(\mathbf{1})$ or $\mathrm{F}(2)$. The ${ }^{1} \mathrm{H}$ and ${ }^{13} \mathrm{C}$ NMR data of fuzanin I (5) (Table 1) showed no signals due to an olefinic methyl group corresponding to C-14 of 1-4, whereas two doublet methyl signals were observed and were assigned to C-13 and C-14 positions. The ${ }^{1} \mathrm{H}-{ }^{1} \mathrm{H}$ COSY spectrum showed that the methylene protons on $\mathrm{C}-2\left(\mathrm{H}_{2}-2, \delta_{\mathrm{H}} 3.71\right.$ and 3.22$)$ were connected to another methylene group $\left(\mathrm{H}_{2}-3, \delta_{\mathrm{H}} 1.81\right.$ and 1.72), which in turn was coupled to an $\mathrm{sp}^{3}$ oxymethine proton at $\mathrm{C}-4\left(\mathrm{H}-4, \delta_{\mathrm{H}} 3.97\right)$. The HMBC spectrum revealed correlations from the methyl protons on $\mathrm{C}-14\left(\mathrm{H}_{3}-14, \delta_{\mathrm{H}} 0.98\right)$ to the oxymethine carbon $\left(\mathrm{C}-4, \delta_{\mathrm{C}} 68.2\right)$ and two other $\mathrm{sp}^{3}$ methines $\left(\mathrm{C}-5, \delta_{\mathrm{C}} 42.1\right.$; C-6, $\left.\delta_{\mathrm{C}} 60.4\right)$. From these observations, it was suggested that the $\mathrm{C}-4 / \mathrm{C}-5$ position of 5 was saturated and a secondary hydroxyl group was located at the C-4 position instead of $\mathrm{C}-3$ position. The ${ }^{1} \mathrm{H}-{ }^{1} \mathrm{H}$ COSY and $\mathrm{HMBC}$ spectra indicated that the structure of the rest of the molecule of 5 (C-6 to C-13 part) was identical to that of fuzanin E (1). The coupling constant between $\mathrm{H}-5$ and $\mathrm{H}-6$ was large $(J=10.5 \mathrm{~Hz})$, suggesting that these two hydrogens were both axial. The oxymethine proton $(\mathrm{H}-$ 4) was observed as a broad singlet, thus implying that this hydrogen had small coupling constants with neighboring hydrogens and was therefore equatorial. These observations revealed $4 \beta-\mathrm{OH}, 5 \beta-\mathrm{CH}_{3}$ and $6 \beta-\mathrm{H}$ configurations for 5 . The $\mathrm{H}-6 / \mathrm{H}-7$ configuration was suggested as anti from the diagnostic ${ }^{1} \mathrm{H}$ NMR chemical shifts of $\mathrm{H}-7$ and $\mathrm{H}-8$, as shown in Table 2, although the chemical shift of H-6 of $\mathbf{5}$ was slightly different from those of $\mathbf{1}$ or 3 due to the C-5 position being sp $\mathrm{s}^{3}$ or $\mathrm{sp}^{2}$. This configuration was also supported by the observation of significant NOE from H-6 to H-8 for 5. From these results, the structure $\mathbf{5}$ was assigned to fuzanin I. The absolute configuration of $\mathbf{5}$ remained undefined because the modified Mosher's method could not be applied on $\mathbf{5}$ due to small quantity.

We examined the bioactivity of fuzanins E-H (1-4) using cell-based assay systems constructed in our laboratories targeting Wnt signaling pathways, but these compounds did not exhibit inhibition of Wnt signal transcription activity even at $100 \mu \mathrm{M}$ using a luciferase reporter gene assay in SuperTOP-Flash transfected cells. ${ }^{7}$ Fuzanins E-I (1-5) also did not show antimicrobial activity at $100 \mu \mathrm{g}$ per disc against Bacillus subtilis.

\section{MATERIALS AND METHODS}

\section{General}

Optical rotations were measured with a JASCOP-1020 polarimeter (JASCO, Tokyo, Japan). IR spectra were measured on ATR (attenuated total reflection) on a JASCO FT-IR 230 spectrophotometer. UV spectra were measured on a Shimadzu UV mini-1240 spectrometer (Shimadzu, Kyoto, Japan). NMR spectra were recorded on JEOL JNM-A400 and JEOL JNM-ECP600 spectrometers (JEOL, Tokyo, Japan) with a deuterated solvent, the chemical shift of which was used as an internal standard. FABMS were obtained on a JEOL AX-500 spectrophotometer, and HRFABMS were obtained on a JEOL HX-110 mass spectrometer. HRESIMS were obtained on an Exactive (Thermo Scientific, Kanagawa, Japan).

\section{Microbial strain}

Kitasatospora sp. IFM 10917 was separated from a soil sample collected in Toyama City, Japan in March 2007, as described previously. ${ }^{5}$ The identification was carried out by Professor Yuzuru Mikami of the Medical Mycology Research Center, Chiba University, where a voucher specimen is deposited with code IFM 10917.

\section{Extraction and isolation}

The culture broth (61 total), obtained as described previously, ${ }^{5}$ was harvested and centrifuged to separate the mycelia and supernatant. The supernatant was concentrated under reduced pressure to $500 \mathrm{ml}$ and partitioned between EtOAc $(500 \mathrm{ml} \times 3)$ to give the EtOAc-soluble fraction $(937 \mathrm{mg})$. This material was subjected to silica gel column chromatography $(25 \times 450 \mathrm{~mm})$ eluted with a gradient of mixtures (hexane/EtOAc $=1: 1,4: 6,3: 7,1: 4$, and $\mathrm{MeOH}$ ) to give 14 fractions $1 \mathrm{~A}$ to $1 \mathrm{~N}$, which were subjected to TLC examination, and three fractions (1I, $1 \mathrm{~J}$ and $1 \mathrm{~K}$ ) were selected as anisaldehyde-positive fractions, which were suggested to contain previously isolated fuzanins $A-D^{5}$ and other related compounds. Fraction 1I (26.8 mg) eluted with hexane/EtOAc (2:8) was purified by Sephadex LH-20 column chromatography $(10 \times 450 \mathrm{~mm})$ eluted with $\mathrm{MeOH}$, followed by preparative HPLC (YMC-Pack ODS-AM, $10 \times 250 \mathrm{~mm}$; eluent, $50 \% \mathrm{MeOH}$; flow rate, $1.0 \mathrm{ml} \mathrm{min}^{-1}$; UV detection at $254 \mathrm{~nm}$; YMC Co Ltd, Kyoto, Japan) to afford fuzanin G (3, 2.2 mg, Rt (retention time) $24.0 \mathrm{~min}$ ) and fuzanin $\mathrm{H}(4,2.4 \mathrm{mg}$, Rt $20.5 \mathrm{~min})$. Fraction $1 \mathrm{~J}(27.1 \mathrm{mg})$ eluted with hexane/EtOAc (2:8) was fractionated by Sephadex LH-20 column chromatography $(10 \times 450 \mathrm{~mm})$ eluted with $\mathrm{MeOH}$, followed by preparative HPLC (YMC-Pack ODS-AM, $10 \times 250 \mathrm{~mm}$; eluent, $50 \% \mathrm{MeOH}$; flow rate, $1.0 \mathrm{ml} \mathrm{min}^{-1}$; UV detection at $\left.254 \mathrm{~nm}\right)$ to give fuzanin $\mathrm{E}(1,3.5 \mathrm{mg}$, Rt $27.0 \mathrm{~min})$, fuzanin $\mathrm{F}(2,2.2 \mathrm{mg}$, Rt $22.0 \mathrm{~min})$ and fuzanin $\mathrm{H}(\mathbf{4}, 0.9 \mathrm{mg}$, Rt $20.0 \mathrm{~min})$. Fraction $1 \mathrm{~K}(25.6 \mathrm{mg})$ eluted with hexane/EtOAc $(0: 1)$ was separated by Sephadex LH-20 column chromatography $(13 \times 400 \mathrm{~mm})$ eluted with $\mathrm{MeOH}$, followed by preparative HPLC (Develosil ODS UG-5, 10×250 mm; eluent, $50 \% \mathrm{MeOH}$; flow rate, $1.0 \mathrm{ml} \mathrm{min}^{-1}$; UV detection at $254 \mathrm{~nm}$ ) to afford fuzanin F (2, 2.4 mg, Rt 23.0 min) and fuzanin I (5, $1.2 \mathrm{mg}$, Rt $31.5 \mathrm{~min})$.

\section{Fuzanin E (1)}

Colorless oil, $[\alpha]_{\mathrm{D}}{ }^{24}-2.9$ (c 1.0, MeOH); IR $v_{\max }$ (ATR) 3360 and $1736 \mathrm{~cm}^{-1}$; ${ }^{1} \mathrm{H}$ and ${ }^{13} \mathrm{C}$ NMR data in Table 1; FABMS $m / z 268(\mathrm{M}+\mathrm{H})^{+}$and $306(\mathrm{M}+\mathrm{K})^{+}$; HRFABMS $m / z 268.1560(\mathrm{M}+\mathrm{H})^{+}$, calcd for $\mathrm{C}_{14} \mathrm{H}_{22} \mathrm{NO}_{4}, 268.1549$.

\section{Fuzanin F (2)}

Colorless oil, $[\alpha]_{D}{ }^{16}+10.6$ (c 1.0, MeOH); IR $v_{\max }$ (ATR) 3368 and $1734 \mathrm{~cm}^{-1}$; ${ }^{1} \mathrm{H}$ and ${ }^{13} \mathrm{C}$ NMR data in Table 1; HRESIMS $\mathrm{m} / \mathrm{z} 290.1358(\mathrm{M}+\mathrm{Na})^{+}$, calcd for $\mathrm{C}_{14} \mathrm{H}_{21} \mathrm{NO}_{4} \mathrm{Na}, 290.1363$.

\section{Fuzanin G (3)}

Colorless oil, $[\alpha]_{\mathrm{D}}{ }^{24}-2.5$ (c 1.0, MeOH); IR $v_{\max }$ (ATR) ca. 3300, 1739 and $1713 \mathrm{~cm}^{-1}$; ${ }^{1} \mathrm{H}$ and ${ }^{13} \mathrm{C}$ NMR data in Table 1; FABMS $\mathrm{m} / z 265\left[\mathrm{M}^{+}\right]$and 304 $(\mathrm{M}+\mathrm{K})^{+}$; HRFABMS $\mathrm{m} / \mathrm{z} 288.1199(\mathrm{M}+\mathrm{Na})^{+}$, calcd for $\mathrm{C}_{14} \mathrm{H}_{19} \mathrm{NO}_{4} \mathrm{Na}$, 288.1212 .

\section{Fuzanin $\mathrm{H}(4)$}

Colorless oil, $[\alpha]_{\mathrm{D}}{ }^{16}+20.2\left(c\right.$ 1.0, MeOH); IR $v_{\max }$ (ATR) ca. 3300, 1741 and $1715 \mathrm{~cm}^{-1} ;{ }^{1} \mathrm{H}$ and ${ }^{13} \mathrm{C}$ NMR data in Table 1; HRESIMS $\mathrm{m} / \mathrm{z} 288.1201$ $(\mathrm{M}+\mathrm{Na})^{+}$, calcd for $\mathrm{C}_{14} \mathrm{H}_{19} \mathrm{NO}_{4} \mathrm{Na}, 288.1212$. 


\section{Fuzanin I (5)}

Colorless oil, $[\alpha]_{\mathrm{D}}{ }^{24}-4.8\left(\right.$ c 1.0, MeOH); IR $v_{\max }$ (ATR) 3383 and $1732 \mathrm{~cm}^{-1}$; ${ }^{1} \mathrm{H}$ and ${ }^{13} \mathrm{C}$ NMR data in Table 1; HRESIMS $\mathrm{m} / \mathrm{z} 292.1513(\mathrm{M}+\mathrm{Na})^{+}$, calcd for $\mathrm{C}_{14} \mathrm{H}_{23} \mathrm{NO}_{4} \mathrm{Na}, 292.1525$.

\section{Preparation of Mosher's esters derivatives}

Fuzanin E (1) (1.1 mg) was treated with $(R)$-MTPA-Cl $(8 \mu \mathrm{l}, 10.4 \mathrm{mg})$ in pyridine $(8 \mu \mathrm{l})$ at room temperature for $24 \mathrm{~h}$, and the mixture was evaporated under reduced pressure. The residue was purified by silica gel chromatography $(7 \times 65 \mathrm{~mm}$, hexane/EtOAc $=1: 1)$ to give the $(S)$-MTPA diester of $1(2.8 \mathrm{mg})$ : ESIMS, $m / z 722(\mathrm{M}+\mathrm{Na})^{+}$. Fuzanin E (1) was also treated with $(S)-\mathrm{MTPA}-\mathrm{Cl}$ by the same procedures as above to afford (R)-MTPA diester of 1 : ESIMS, $m / z 722$ $(\mathrm{M}+\mathrm{Na})^{+}$. Corresponding $(S)$ - and $(R)$-MTPA esters of $\mathbf{2}-\mathbf{5}$ were prepared by the same procedures as above. (S)-MTPA ester of 2: ESIMS, $m / z 722(\mathrm{M}+\mathrm{H})^{+}$. $(R)$ MTPA ester of 2: ESIMS, $m / z 722(\mathrm{M}+\mathrm{Na})^{+}$. (S)-MTPA ester of 3: ESIMS, $m / z$ $504(\mathrm{M}+\mathrm{Na})^{+} .(R)$-MTPA ester of 3: ESIMS, $m / z 504(\mathrm{M}+\mathrm{Na})^{+} .(S)$-MTPA ester of 4: ESIMS, $m / z 504(\mathrm{M}+\mathrm{Na})^{+}$. (R)-MTPA ester of 4: ESIMS, $m / z 504(\mathrm{M}+\mathrm{Na})^{+}$.

\section{ACKNOWLEDGEMENTS}

We thank Professor Yuzuru Mikami (Medical Mycology Research Center, Chiba University) for the identification of Kitasatospora sp. IFM10917. This work was supported by Grants-in-Aid for Scientific Research from the Japan Society for the Promotion of Science (JSPS).

1 Ishibashi, M. \& Arai, M. A. Search for bioactive natural products targeting cancer-related signaling pathways. J. Synth. Org. Chem. Jpn. 67, 1094-1104 (2009).

2 Ahmed, F., Ohtsuki, T., Aida, W. \& Ishibashi, M. Tyrosine derivatives isolated from Streptomyces sp. IFM 10937 in a screening program for TRAIL-resistance overcoming activity. J. Nat. Prod. 71, 1963-1966 (2008).

3 Kikuchi, H. et al. Activity of mangosteen xanthones and teleocidin A-2 in death-receptor expression enhancement and tumor necrosis-factor related apoptosis-inducing ligand assays. J. Nat. Prod. 73, 452-455 (2010).

4 Ishibashi, M. \& Ohtsuki, T. Studies on search for bioactive natural products targeting TRAIL signaling leading to tumor cell apoptosis. Med. Res. Rev. 28, 688-714 (2008).

5 Aida, W., Ohtsuki, T., Li, X. \& Ishibashi, M. Isolation of new carbamate- or pyridinecontaining natural products, fuzanins A, B, C, and D from Kitasatospora sp. IFM10917. Tetrahedron 65, 369-373 (2009).

6 Ohtani, I., Kusumi, T., Kashman, Y. \& Kakisawa, H. High-field FT NMR application of Mosher's method. The absolute configurations of marine terpenoids. J. Am. Chem. Soc. 113, 4092-4096 (1991).

7 Li, X., Ohtsuki, T., Koyano, T., Kowithayakorn, T. \& Ishibashi, M. New Wnt/ß-catenin signaling inhibitors isolated from Eleutherine palmifolia. Chem. Asian J. 4, 540-547 (2009). 